\title{
Analysis of the Effect of Profitability Ratio on Stock in Cigarette Companies in Indonesia Stock Exchange
}

\author{
Afriani Lubis \\ Department of Accounting, University of North Sumatra, Indonesia
}

\begin{tabular}{|c|c|}
\hline ARTICLE INFO & ABSTRACT \\
\hline Article history: & \multirow{3}{*}{$\begin{array}{l}\text { This research to determine and analyze the influence of Net Profit } \\
\text { Margin, Return On Asset, and Earning Per Share of Stock Price in } \\
\text { ciagarette companies in Indonesian Stock Exchange. This research } \\
\text { period starting from } 2007 \text { until } 2011 \text {. The hypothesis put forward is } \\
\text { the Net Profit Margin, Return On Asset, and Earning Per Share } \\
\text { simultaneously and partially influenced the Stock Price in ciagarette } \\
\text { companies in the Indonesian Stock Exchange. This research is a } \\
\text { causal associative type of research, namely to measures causal } \\
\text { relationships between two or more variables through hypothesis } \\
\text { testing. The population in this study is the company's ciagarette in } \\
\text { Indonesia Stock Exchange a total of } 3 \text { companies. This research } \\
\text { used saturated sampling and obtained a sample of } 3 \text { companies. } \\
\text { The data used are secondary data_Methods of data analysis using } \\
\text { descriptive analysis method and multiple linear regression analysis. } \\
\text { F test results showed that the independent variables Net Profit } \\
\text { Margin, Return On Asset, and Earning Per Share simultaneously } \\
\text { influential and significant effect on Stock Price. Partial test results } \\
\text { (Test-t) show that the Net Profit Margin, Return On Asset and } \\
\text { Earning Per Share has a significant influence the Stock Price in } \\
\text { ciagarette companies in Indonesian Stock Exchange. }\end{array}$} \\
\hline $\begin{array}{r}\text { Received Dec 05, } 2021 \\
\text { Revised Jan 20, } 2022 \\
\text { Accepted Feb 28, } 2022\end{array}$ & \\
\hline $\begin{array}{r}\text { Profitability Ratio; } \\
\text { Stock Price; } \\
\text { Net Profit Margin (NPM); } \\
\text { Return On Assets (ROA); } \\
\text { Earning Per Share (EPS). }\end{array}$ & \\
\hline
\end{tabular}

This is an open access article under the CC BY-NC license.

\section{INTRODUCTION}

The impact of smoking activities and reduced government support for cigarette companies. This does not reduce the interest of investors to engage in cigarette companies, so that the prospects can provide benefits for the company both now and in the future.

In addition, seeing the high level of consumption and production of cigarettes in Indonesia will create stiff competition for cigarette companies. This condition will be a challenge for large-scale local cigarette companies such as Sampoerna, Gudang Garam, Bentoel/BAT, to make a more aggressive strategy in running their business and improve company performance.

Financial ratio analysis is useful for investors to identify the company's financial condition and company's financial performance. One of the financial ratios that are useful for investors is the profitability ratio. The profitability ratio will provide an overview of how effective and efficient the company's management is in managing all its resources to obtain optimal profits during a certain period. If this ratio is high, of course, it will be better for the company. 
Stock prices reflect the value of a company. Therefore, investors and shareholders must be able to pay attention to the company's financial performance. If the company's financial performance is good, it allows the company to achieve maximum profits and will be an attraction for investors to invest in the company. With many investors who want the company's shares, resulting in changes in stock prices.

Stock prices have a relationship with the level of profit earned from the company. A high level of profit will support an increase in stock prices. The research I did was a replication of Romi Batu Ginta Tarigan's research (2010). In this study the independent variables that I use are Net Profit Margin (NPM), Return on Assets (ROA) and Earning Per Share (EPS). While Romi Batu Ginta Tarigan's research (2010) uses the ratio of Earning Per Share (EPS), Net Profit Margin (NPM), Return on Assets (ROA) and Return on Equity (ROE) with the same dependent variable, namely stock prices. The research object that I use is also different, in this study I used the research object of the cigarette company, while the research object of Romi Batu Ginta Tarigan (2010) used the research object of the food and beverage industry company with the same number of years of observation.

\section{RESEARCH METHOD}

This type of research is associative with a causal relationship, namely measuring the causal relationship between two or more variables through hypothesis testing. According to Daulay (2010:10), associative research is research that aims to determine the relationship between two or more variables, while a causal relationship is a causal relationship, if $\mathrm{X}$ then $\mathrm{Y}$.

\subsection{Method of collecting data}

The method of data collection in this study was carried out through library research, namely accounting journals, books, previous research related to the problem under study and through secondary data collection required in the form of financial statements of cigarette companies published on the Indonesia Stock Exchange.

\subsection{Data analysis method}

\section{a. Descriptive Analysis}

Sangadji and Sopiah (2010:210) state that descriptive analysis is an analysis that prefers to describe the facts as they are. In addition, this analysis also aims to collect, classify, analyze, present, and describe data systematically and objectively, thus providing information and an overview of the object under study.

\section{b. Classic Assumption}

The classical assumption requirements that must be met by the multiple regression model before the data are analyzed are as follows:

1) Normality test. According to Situmorang et.al (2010: 91) the normality test is carried out to test whether the distribution of a data follows or approaches the normal distribution, namely the distribution of data with a bell shape. Normality test was carried out through graph analysis and Kolmogorov-Smirnov (KS) analysis.

2) Heteroscedasticity Test. Sangadji and Sopiah (2010:249) stated that the heteroscedasticity test resulted in the predictive ability of the coefficients in the model being inefficient and not having much significance. If the residual variance from one observation to another observation remains, it is called homoscedasticity and if it is different it is called heteroscedasticity.

3) Autocorrelation Test. According to Situmorang et.al (2010:113) autocorrelation test aims to test whether there is a correlation between the nuisance error in period $t$ and errors in period t 1 or before. Autocorrelation arises because successive observations over time are related to each other. This problem arises because the residual or nuisance error is not independent from one observation to another. This usually occurs in time series data. Because interference in one data tends to interfere with other data. 


\section{RESULTS AND DISCUSSIONS}

\subsection{Desk Analysisriptif}

Based on data analysis of cigarette companies on the Indonesia Stock Exchange, data on the value of financial ratios can be described as follows:

\section{a. Stock Price}

The share price is calculated from the closing price of the cigarette company in each transaction five days before the closing of the book (end of the semester) which is calculated from transactions five days after the closing of the book (beginning of the semester) to become the average share price of the cigarette company.

Table 1. Cigarette Company's share price on the IDX for the period 2007-2011 (rupiah)

\begin{tabular}{cccccccccccc}
\hline Code & \multicolumn{2}{c}{2007} & \multicolumn{2}{c}{2008} & \multicolumn{2}{c}{2009} & \multicolumn{2}{c}{2010} & \multicolumn{2}{c}{2011} & Flat- \\
\hline Company & SI & S-II & SI & S-II & SI & S-II & SI & S-II & SI & S-II & Flat \\
RMB & 313 & 522 & 492 & 1,001 & 840 & 621 & 396 & 797 & 833 & 795 & 661 \\
GGRM & 11,090 & 8,440 & 5,860 & 4,505 & 12,120 & 21.085 & 34,070 & 40,065 & 48,625 & 61,765 & 24,763 \\
HMSP & 13,760 & 14.205 & 10,065 & 8,810 & 9,265 & 10,445 & 18,690 & 28.085 & 28,520 & 39,050 & 18.090 \\
Average Per & & & & & & & & & & & \\
Semester & 8,388 & 7,722 & 5,472 & 4,772 & 7,408 & 10,717 & 17,719 & 22,982 & 25,993 & 33,870 & 14,504 \\
\hline
\end{tabular}

Source: Research Results, 2012 (processed data)

Table 1 describes the average share price of each cigarette company on the Indonesia Stock Exchange during 2007 to 2011. In Table 4.1 it can be seen that the average share price fluctuated, the company having the highest average share price during the year The observation is PT Gudang Garam Tbk (GGRM) of Rp. 24,763. The company that has the lowest average share price is PT Bentoel Internasional Investama Tbk (RMBA) at Rp661.

In 2007, the average share price in the first and second semesters was Rp8,388 and Rp7,722. The company with the highest share price was PT HM Sampoerna Tbk (HMSP) at Rp14,205 in the second semester and the company with the lowest share price was PT Bontoel Internasional Investama Tbk (RMBA) at Rp313 in the first semester.

In 2008, the average share price in the first and second semesters decreased from 2007 to Rp5,472 and Rp4,772, respectively. The company with the highest share price was PT HM Sampoerna Tbk (HMSP) at Rp. 10,065 in the first semester and the company with the lowest share price was PT Bontoel Internasional Investama Tbk (RMBA) at Rp.492 in the first semester.

In 2009 the average share price in the first and second semesters increased from 2008 to $R p 7,408$ and Rp10,717. The company with the highest share price was PT Gudang Garam Tbk (GGRM) at Rp. 21,085 in the second semester and the company with the lowest share price was PT Bontoel Internasional Investama Tbk (RMBA) at Rp. 621 in the second semester.

In 2010 the average share price in the first and second semesters increased from 2009 to Rp17,719 and Rp22,982, respectively. The company with the highest share price was PT Gudang Garam Tbk (GGRM) at Rp40,065 in the second semester and the company with the lowest share price was PT Bontoel Internasional Investama Tbk (RMBA) at Rp395.5 in the first semester.

\section{b. Net Profit Margin (NPM)}

Net Profit Margin shows the comparison between net income and sales. Net Profit Margin measures how well the company manages its business activities to earn a profit.

Table 2. Net Profit Margin Cigarette Companies on IDX for the period 2007-2011(\%)

\begin{tabular}{ccccccccccccc}
\hline Code & \multicolumn{2}{c}{2007} & \multicolumn{2}{c}{2008} & \multicolumn{2}{c}{2009} & \multicolumn{2}{c}{2010} & \multicolumn{2}{c}{2011} & Flat- \\
\hline Company & SI & S-II & SI & S-II & SI & S-II & SI & S-II & SI & S-II & Flat \\
RMB & 5.41 & 5.3 & 3.05 & 4.03 & 0.81 & 0.41 & 2.58 & 2.46 & 3.78 & 3.04 & 3.09 \\
GGRM & 5.29 & 5.13 & 5.92 & 6.22 & 9.51 & 10.5 & 9.89 & 11 & 11.7 & 11.8 & 8.7 \\
HMSP & 14.37 & 12.2 & 11.77 & 11.23 & 13.5 & 13.1 & 14.06 & 14.8 & 15.4 & 15.2 & 13.6 \\
Average Per & & & & & & & & & & & & \\
Semester & 8.36 & 7.53 & 6.91 & 7.16 & 7.95 & 7.98 & 8.84 & 9.42 & 10.3 & 10.04 & 8.45 \\
\hline
\end{tabular}

Source: Research Results, 2012 (processed data) 
Table 2 describes the NPM value of each cigarette company on the Indonesia Stock Exchange from 2007 to 2011. The average NPM of all companies during the year of observation was $8.45 \%$. In Table 4.2, it can be seen that the average NPM fluctuated. The company that had the highest average NPM during the year of observation was PT HM Sampoerna Tbk (HMSP) which was $13.6 \%$. Meanwhile, the company that has the lowest average NPM is PT Bentoel Internasional Investama (RMBA), which is $3.09 \%$.

\section{c. Return on Assets (ROA)}

Return On Assets shows the comparison between net income and total assets. This ratio is useful for evaluating company profitability.

Table 3. Return On Assets Cigarette Companies on IDX for the period 2007-2011(\%)

\begin{tabular}{ccccccccccccc}
\hline Code & \multicolumn{2}{c}{2007} & \multicolumn{2}{c}{2008} & \multicolumn{2}{c}{2009} & \multicolumn{2}{c}{2010} & \multicolumn{2}{c}{2011} & Flat- \\
\hline Company & SI & S-II & SI & S-II & SI & S-II & SI & S-II & SI & S-II & Flat \\
RMB & 4.13 & 6.29 & 2.15 & 5.37 & 0.54 & 0.58 & 2.35 & 4.46 & 4.24 & 4.83 & 3.49 \\
GGRM & 3.25 & 6.03 & 3.58 & 7.81 & 5.72 & 12.69 & 6.52 & 13.49 & 7.56 & 12.68 & 7.93 \\
HMSP & 14.07 & 23.11 & 13.44 & 24.14 & 14.56 & 28.72 & 16.27 & 31.29 & 24.08 & 41.55 & 23.12 \\
Average Per & & & & & & & & & & & \\
Semester & 7.15 & 11.81 & 6.39 & 12.44 & 6.94 & 14.00 & 8.38 & 16.41 & 11.96 & 19.69 & 11.52 \\
\hline
\end{tabular}

Source: Research Results, 2012 (processed data)

Table 3 describes the ROA value of each cigarette company on the Indonesia Stock Exchange during 2007 to 2011. The average ROA of all companies during the year of observation was $11.52 \%$. In Table 4.3, it can be seen that the average ROA fluctuated. The company that had the highest average ROA during the year of observation was PT HM Sampoerna Tbk (HMSP) which was $23.12 \%$. Meanwhile, the company that has the lowest average ROA is PT Bentoel Internasional Investama (RMBA), which is $3.49 \%$.

\section{d. Earnings Per Share (EPS)}

Earnings per Share shows the ratio of net income to the number of shares outstanding. This ratio is used to measure the success of management in achieving profits for shareholders.

Table 4. Earning Per Share Cigarette Companies on the IDX for the period 2007-2011(rupiah)

\begin{tabular}{cccccccccccc}
\hline Code & \multicolumn{2}{c}{2007} & \multicolumn{2}{c}{2008} & \multicolumn{2}{c}{2009} & \multicolumn{2}{c}{2010} & \multicolumn{2}{c}{2011} & Flat- \\
\hline Company & SI & S-II & SI & S-II & SI & S-II & SI & S-II & SI & S-II & Flat \\
RMB & 18.02 & 39.00 & 13.87 & 35.52 & 3.44 & 3.74 & 15.55 & 30.20 & 33.86 & 42.26 & 23.55 \\
GGRM & 369.30 & 750.27 & 463.26 & 977.34 & 744.70 & $1,796.02$ & 925.23 & $2,154.93$ & $1,208.48$ & $2,576.86$ & $1,196.64$ \\
HMSP & 473.37 & 826.84 & 448.27 & 888.72 & 575.65 & $1,160.70$ & 661.29 & $1,465.08$ & 867.63 & $1,836.88$ & 920.44 \\
Average Per & & & & & & & & & & & \\
Semester & 286.89 & 538.70 & 308.47 & 633.86 & 441.26 & 986.82 & 534.03 & $1,216.74$ & 703.32 & $1,485.34$ & 713.54 \\
\hline
\end{tabular}

Source: Research Results, 2012 (processed data)

Table 4 describes the average EPS of each cigarette company on the Indonesia Stock Exchange during 2007 to 2011. In Table 4.4 it can be seen that the average EPS fluctuated, the company that had the highest average EPS during the year of observation was PT Gudang Garam Tbk (GGRM) amounting to Rp 1,196.64. The company that has the lowest average share price is PT. Bentoel Internasional Investama Tbk (RMBA) at Rp23.55.

\subsection{Classical Assumption Test}

The classical assumption requirements that must be met by the multiple regression model before the data are analyzed are as follows:

\section{a. Normality Test}

Normality test was carried out through graph analysis and Kolmogorov-Smirnov (KS) analysis. The statistical test of the graphic model can be detected by looking at the spread of data (points) on the diagonal axis and the graph by looking at the histogram of the residuals. To find out whether the data is normally distributed or not, the Kolmogorov Smirnov test is carried out by looking at the residual data whether the distribution is normal or not. 

follows:

The results of the normality test using the graph model and Kolmogorov-Smirnov are as

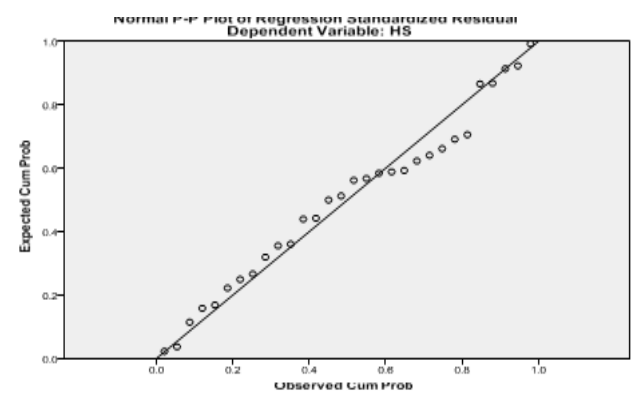

Figure 1. Normal PP Plot

Figure 1 shows that the points follow a diagonal line, this indicates that the data is normally distributed.

Table 5. Normality Test

One-Sample Kolmogorov-Smirnov Test

\begin{tabular}{ccc}
\hline & & Unstandardized Residual \\
\hline $\mathrm{N}$ & mean & 30 \\
Normal Parameters, b & Std. Deviation & .0000000 \\
Most Extreme & Absolute & $7.34612602 \mathrm{E} 3$ \\
Differences & Positive & .118 \\
\multicolumn{2}{c}{ Kolmogorov-Smirnov Z } & .118 \\
negative & -.069 \\
asymp. Sig. (2-tailed) & .645 \\
\hline Source: SPSS 18 for windows data processing (December 20, 2012, processed)
\end{tabular}

From Table 5 it can be seen that the Asymp value. Sig (2-tailed) is 0.800 (greater than the significance level $=0.05$ ). Thus it can be concluded that the residual data is normally distributed.

b. Heteroscedasticity Test

A good regression model is one that does not occur heteroscedasticity. One way to detect the presence or absence of heteroscedasticity is to look at the graph plot through the scatterplot image as follows:

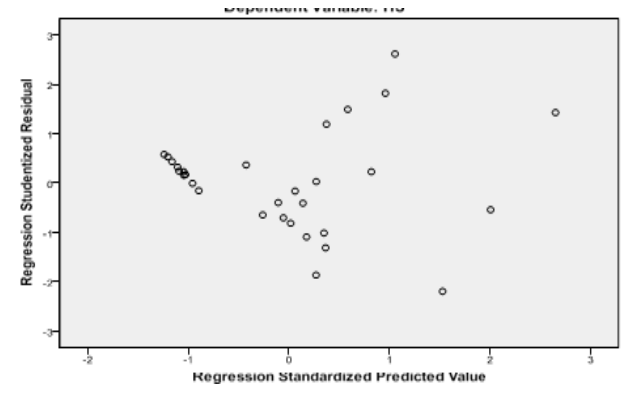

Figure 2. Scatterplot

In Figure 2 it can be seen that the points spread above and below zero on the $\mathrm{Y}$ axis and there is no clear pattern, it can be concluded that there is no heteroscedasticity.

\section{c. Autocorrelation Test}

One way to find out whether there is autocorrelation in the regression model is to perform the Durbin Watson (DW) test. When the value of DW is locatedbetween -2 to +2 means there is no 
autocorrelation. The results of the autocorrelation test carried out with SPSS 18 for windows are shown in the following table:

Table 6. Autocorrelation Test Model Summaryb

\begin{tabular}{cccccc}
\hline Model & $\mathbf{R}$ & R Square & $\begin{array}{c}\text { Adjusted R } \\
\text { Square }\end{array}$ & $\begin{array}{c}\text { Std. Error of } \\
\text { the Estimate }\end{array}$ & $\begin{array}{c}\text { Durbin- } \\
\text { Watson }\end{array}$ \\
\hline $\begin{array}{c}\text { n0 dime } \\
\text { nsio }\end{array}$ & $.893 a$ & .797 & .774 & 7758.37379 \\
\hline
\end{tabular}

Predictors: (Constant), EPS, ROA, NPM

Dependent Variable: HS

Source: SPSS 18 for windows data processing (December 20, 2012, processed)

Table 6 above shows that the DW value obtained is 1.391 which means it lies between -2 to +2 , so that it can be concluded that in the regression equation there is no autocorrelation.

\section{d. Multicollinearity Test}

The results of multicollinearity testing carried out with SPSS 18 for windows are shown in the following table:

Table 7. Multicollinearity Test Coefficientsa

\begin{tabular}{|c|c|c|c|c|c|c|c|}
\hline \multirow[t]{2}{*}{ Model } & \multicolumn{2}{|c|}{ Unstandardized Coefficients } & \multirow{2}{*}{$\begin{array}{c}\text { Standardized } \\
\text { Coefficients } \\
\text { Beta }\end{array}$} & \multirow[b]{2}{*}{$T$} & \multirow[b]{2}{*}{ Sig. } & \multicolumn{2}{|c|}{ Collinearity Statistics } \\
\hline & B & Std. Error & & & & Tolerance & VIF \\
\hline (Constant) & -3875.248 & 3028.326 & & $-1,280$ & .212 & & \\
\hline NPM & 132749,509 & 57014,582 & 389 & 2,328 & .028 & .280 & 3.571 \\
\hline $\mathrm{ROA}$ & $-53166,031$ & 24439.014 & -.332 & -2.175 & .039 & .334 & 2,994 \\
\hline EPS & 18,636 & 2,793 & .801 & 6.673 & .000 & .541 & 1,847 \\
\hline
\end{tabular}

a. Dependent Variable: HS

Source: SPSS 18 for windows data processing (December 20, 2012, processed)

Table 7 can be seen that all independent variables do not have multicollinearity problems. This can be seen from the value of VIF $<5$ and Tolerance $>0.1$.

\subsection{Multiple Linear Regression Analysis}

Multiple linear regression analysis was conducted to determine the effect of the independent variables, namely Net Profit Margin, Return On Assets, Earning Per Share on stock prices.

\section{a. Coefficient of Determination (R2)}

Table 8. Model Summaryb

\begin{tabular}{|c|c|c|c|c|c|}
\hline Model & $\mathbf{R}$ & R Square & Adjusted R Square & Std. Error of the Estimate & \\
\hline no & $\begin{array}{l}\text { dime } \\
\text { nsio }\end{array}$ & $.893 a$ & .797 & .774 & 7758.37379 \\
\hline
\end{tabular}

Predictors: (Constant), EPS, ROA, NPM

Dependent Variable: HS

Source: Processed results of SPSS 18 for windows (20 December 2012, processed)

Information :

1) $\mathrm{R}=0.893$ means the relationship between Net Profit Margin, Return On Assets, Earning Per Share on the stock price of $89.3 \%$. This means that the relationship is very close.

2) Adjusted $\mathrm{R}$ Square of 0.774 means that $77.4 \%$ of stock price factors can be explained by Net Profit Margin, Return On Assets, Earning Per Share. While the remaining $22.6 \%$ can be explained by other factors not examined in this study. 


\subsection{Hypothesis test}

a. Simultaneous Test (F Test)

The $\mathrm{F}$ test was conducted to determine how the influence of the independent variable on the dependent variable simultaneously. The hypotheses to be tested are:

$\mathrm{H} 0: 1=2=3=0$, meaning that Net Profit Margin (X1), Return On Assets (X2), Earning Per Share $(\mathrm{X} 3)$ simultaneously have no effect on stock prices $(\mathrm{Y})$.

H1 : 123 0, meaning that Net Profit Margin (X1), Return On Assets (X2), Earning Per Share (X3) simultaneously affect stock prices (Y).

This test is carried out by comparing the significance of Fcount with the following conditions: If

Fcount $<$ Ftable at $=5 \%$ If Fcount $>$ Ftable at $=5 \%$ Or you can also use significant values:

1) If $\mathrm{Sig}<0.05=\mathrm{Ho}$ is rejected so that $\mathrm{H} 1$ is accepted, it means that it has a significant effect.

2) If $\mathrm{Sig}>0.05=\mathrm{Ho}$ is accepted so that $\mathrm{H} 1$ is rejected, it means that it has no significant effect.

Table 9. ANOVAb

\begin{tabular}{ccccccc}
\hline & Model & Sum of Squares & df & Mean Square & F & Sig. \\
\hline 1 & Regression & $6.156 \mathrm{E} 9$ & 3 & $2.052 \mathrm{E} 9$ & 34,088 & $.000 \mathrm{a}$ \\
& Residual & $1.565 \mathrm{E} 9$ & 26 & $6.019 \mathrm{E} 7$ & & \\
Total & $7.721 \mathrm{E} 9$ & 29 & & & \\
\hline
\end{tabular}

Predictors: (Constant), EPS, ROA, NPM

Dependent Variable: HS

Source: SPSS 18 for windows data processing (December 20, 2012, processed)

\section{b. Partial Test (t Test)}

Partial test ( $\mathrm{t}$ test) was conducted to determine whether the independent variable partially has a significant effect on the dependent variable. The hypotheses to be tested are:

$\mathrm{H} 0: 1=2=3=0$, meaning that Net Profit Margin (X1), Return On Assets (X2), Earning Per Share $(\mathrm{X} 3)$ partially have no effect on stock prices $(\mathrm{Y})$.

H1 : 123 0, meaning that Net Profit Margin (X1), Return On Assets (X2), Earning Per Share (X3) partially affect stock prices $(Y)$.

Table 10. coefficientsa

\begin{tabular}{ccccccc}
\hline & Model & \multicolumn{2}{c}{ Unstandardized } & \multicolumn{2}{c}{$\begin{array}{c}\text { Standardized } \\
\text { Coefficients }\end{array}$} \\
& \multicolumn{7}{c}{ Coefficients } & C & Std. Error & Beta & T & Sig. \\
\hline 1 & (Constant) & -3875.248 & 3028.326 & & $-1,280$ & .212 \\
& NPM & 132749,509 & 57014,582 & .389 & 2,328 & .028 \\
& ROA & $-53166,031$ & 24439.014 & -.332 & -2.175 & .039 \\
& EPS & 18,636 & 2,793 & .801 & 6.673 & .000 \\
\hline
\end{tabular}

Based on Table 10 to determine the effect of the independent variables (Net Profit Margin,

Return On Assets, Earning Per Share.) partially on the dependent variable (stock price) in cigarette companies are as follows:

1) The variable Net Profit Margin (NPM) has a tcount of 2,328 with a significant value of 0.028 .

By using the t-test table, obtained t-table of 2.045. This shows that tcount is 2,328 $>$ ttable is 2,045, so $\mathrm{H} 1$ is accepted. The significant value of the Net Profit Margin variable is $0.028<$ from significant 0.05 , which means that the variable affects the dependent variable significantly. This means that partially Net Profit Margin has a significant influence on stock prices. The Return On Asset $(R O A)$ variable has a tcount of -2.175 with a significant value of 0.039 . By using the t-test table, obtained t-table of 2.045. This shows that tcount is $-2.175<$ ttable is 2.045 , so $\mathrm{HO}$ is rejected. The significant value of the Return On Assets variable is 0.039 < from significant 0.05 which means that the variable affects the dependent variable significantly. This means that partially Net Profit Margin has a significant influence on stock prices.

2) The Earning Per Share (EPS) variable has a tcount of 6.673 with a significant value of 0.000 . By using the t-test table, obtained t-table of 2.045. This shows that tcount is $6.673>$ ttable is 2.045, so $\mathrm{H} 1$ is accepted. The significant value of the Earning Per Share variable is $0.000<$ 
from significant 0.05 , which means that the variable affects the dependent variable significantly. This means that partially Net Profit Margin has a significant influence on stock prices.

From Table 10, the following multiple linear regression equation is obtained: $\mathrm{HS}=-3875,248$ + 132749,509NPM -53166.031ROA + 18,636EPS Model interpretation:

1) A constant of $-3875,248$. This shows that if there are no independent variables, namely NPM, ROA and EPS, the stock price is Rp-3875.

2) The regression coefficient for the NPM variable is $132,749,509$ which states that for each additional NPM of one unit, the stock price will increase by Rp. 132,749. Assuming other variables are considered constant.

3) The regression coefficient for the ROA variable is $-53,166.031$ which means that for every additional ROA of one unit, the stock price will decrease by Rp. 53,166 units. Assuming other variables are considered constant.

4) The regression coefficient for the EPS variable is 18.636 which states that for each additional EPS of one unit, the stock price will increase by Rp. 18. Assuming other variables are considered constant.

\section{CONCLUSION}

The test results simultaneously or simultaneously (F-Test) show that the independent variables consisting of Net Profit Margin, Return On Assets, and Earning Per Share simultaneously have a significant effect on the stock price of cigarette companies. It can be seen from Fcount (34.088) > Ftable $(2.98)$ and the significant level $(0.000)<0.05$. The test results above show that Net Profit Margin, Return On Assets, Earning Per Share have a major influence on the company's stock price. So that it can influence investors to invest in cigarette companies. Hypothesis testing with the t-test method (partial effect test) can be concluded as follows:

The Net Profit Margin variable partially has a significant effect on stock prices. It can be seen from the tcount of 2,328 > ttable of 2,045 with a significant value of $0.028<$ from 0.05 significant. A positive $t$ value indicates that the Net Profit Margin variable has a direct relationship with stock prices. Where the meaning is if the NPM variable increases, the stock price will increase and vice versa. This proves that the company is able to change the value of sales to earn a profit. Thus, investors can make decisions to invest in cigarette companies. The more investors invest in cigarette companies, the demand for company shares will increase and cause the company's share price to also rise.

The Return On Assets variable partially has a significant effect on stock prices. It can be seen from the tcount of $-2.175<$ ttable of 2.045 with a significant value of $0.039<$ from significant 0.05 . A negative $t$ value indicates that the Return On Asset variable has a negative and significant relationship with stock prices. Where the intention is that if the ROA variable increases, the stock price will decrease and vice versa. This means that the stock price is influenced by other factors such as the interest rate, the amount of cash dividends given, the amount of profit earned by the company, the level of risk and return. Thus, investor confidence will be reduced to invest in cigarette companies.

The Earning Per Share variable partially has a significant effect on stock prices. It can be seen from the tcount of $6.673>$ ttable of 2.045 with a significant value of $0.000<$ from 0.05 significant. A positive t value indicates that the Earning Per Share variable has a direct relationship with stock prices. Where the meaning is if the EPS variable increases, the stock price will increase and vice versa. These results provide the basis for the conclusion that the company's management has succeeded in carrying out the company's performance to achieve profits for shareholders, thus influencing investors and shareholders to buy company shares with the aim of obtaining dividends. The higher the earnings per share given by the company, the high possibility of the company distributing dividends to investors and shareholders. High demand for stocks tends to make stock prices rise. 


\section{REFERENCES}

Anoraga, Pandji. 2001. Pengantar Pasar Modal. Edisi Revisi. Jakarta: PT Rineka Cipta.

Bancin, Lapranto.P. 2007. Pengaruh Profitabilitas Terhadap Perubahan Harga Saham Perusahaan Perbankan di Bursa Efek Indonesia. Skripsi, Fakultas Ekonomi Universitas Sumatera Utara, Tidak Dipublikasikan.

Brigham, Eugene F dan Houston, Joel F. 2001. Manajemen Keuangan. Edisi Kedelapan. Jakarta: Erlangga. 2001. Dasar-Dasar Manajemen Keuangan. Edisi Sembilan. Jakarta: Erlangga.

Brealey, Richard A, Myers Stewart C, dan Marcus Alan J. 2007. Dasar-dasar Manajemen Keuangan Perusahaan. Edisi 5. Jakarta: Erlangga.

Daulay, Murni. 2010. Metodologi Penelitian Ekonomi. Medan: USU Press. Dewi, Nadia Kusuma. 2011. Tantangan Jangka Panjang Industri Rokok Semakin Berat.

Ghozali, Imam. 2005. Aplikasi Analisis Multivariate dengan Program SPSS. Edisi Ketiga. Semarang: Badan Penerbit Universitas Diponegoro.

Hanafi, Mahmud M dan Abdul Halim. 2009. Analisis Laporan Keuangan. Edisi Keempat, UPP STIM YKPN : Yogyakarta

Harahap, Sofyan Syafri. 2006. Analisa Kritis atas Laporan Keuangan. Edisi Pertama. Cetakan Kedua. Jakarta : PT. Raja Grafindo Persada.

Hin, Thian L. 2001. Panduan Berinvestasi Saham. Jakarta: PT Elex Media Komputindo Kelompok Gramedia Jeffrey. 2012. Penilaian Bisnis dengan Menggunakan Laporan Keuangan Pada PT. Gudang Garam, Tbk Tahun 2006-2010. Skripsi, Universitas Bina Nusantara Jakarta, Dipublikasikan.

Jogiyanto, H. M,. 2000. Teori Portfolio dan Analisis Investasi, Edisi Kedua, BPFE-Yogyakarta.

Jusuf, Jopie. 2007. Analisis Kredit Untuk Account Officer. Jakarta: Gramedia.

Kasmir. 2008. Analisis Laporan Keuangan. Jakarta: PT Raja Grafindo Persada.

Kumalasari, Fauziah. 2011. Analisis Pengaruh Kebangkutan Bank dengan Metode Altman Z-Score Terhadap Harga Saham Perusahaan Perbankan di Bursa Efek Indonesia. Skripsi, Fakultas Ekonomi Universitas Sumatera Utara, Tidak Dipublikasikan.

Munawir, S. 2007. Analisis Laporan Keuanngan. Yogyakarta: Penerbit Liberty. Nurmalasari, Indah. 2009. Analisis Pengaruh Rasio Profitabilitas Terhadap Harga

Saham Emiten LQ45 yang Terdaftar di Bursa Efek Indonesia. Artikel, Fakultas Ekonomi Universitas Gunadarma, Dipublikasikan

Purba, Parentahen. 2002. Analisis dan Perencanaan Keuangan. Edisi Satu. Medan: USU Press.

Rahmawati. 2011. Analisis Pengaruh Efektivitas Operasional Terhadap Return On Investment Pada Perusahaan Properti dan Real Estat di Bursa Efek Indonesia. Skripsi, Fakultas Ekonomi Universitas Sumatera Utara, Tidak Dipublikasikan.

Robinson, Ricrhad B dan John A Pearce II. 2007. Manajemen strategis. Edisi Sepuluh. Jakarta: Salemba empat.

Sangadji, Etta Mamang dan Sopiah. 2010. Metedologi Penelitian. Yogyakarta: Penerbit Andi.

Silitonga, Leonardo Guntur H. 2009. Analisis Pengaruh Price Earning Ratio (PER) Return on Equity (ROE) Net Profit Margin Terhadap Harga Saham Pada Industri Rokok di Bursa Efek Indonesia. Skripsi, Fakultas Ekonomi Universitas Sumatera Utara, Tidak Dipublikasikan.

Sitompul, Asril. 2004. Pasar Modal. Bandung: PT Citra Aditya Bakti Situmorang, Syafizal Helmi, Iskandar Muda, Doli M Ja'far, Fauzi Syarif dan Fadli, 2010. Analisis Data Untuk Riset Manajemen dan Bisnis. Medan: USU Press.

Sjahrial, Dermawan. 2009. Manajemen Keuangan. Edisi Ketiga. Jakarta: Mitra Wacana Media.

Sugiono, Arief. 2009. Manajemen Keuangan Untuk Praktisi Keuangan. PT Grasindo : Jakarta

Tarigan, Romi.B.G. 2010. Analisis Pengaruh Rasio Profitabilitas Terhadap Harga Saham Pada Perusahaan Makanan dan Minuman di Bursa Efek Indonesia. Skripsi, Fakultas Ekonomi Universitas Sumatera Utara, Tidak Dipublikasikan.

Usman, Husaini dan Purnomo Setiady Akbar. 2006. Pengantar Statistika. Edisi Kedua. Jakarta: Bumi Aksara.

Widioatmodjo, Sawidji. 2005. Cara Sehat Investasi di Pasar Modal. Jakarta: PT Elex Media Komputindo Kelompok Gramedia.

.2009. Pasar Modal Indonesia. Bogor Selatan: Ghalia Indonesia. Wild,J.J., Subramanyam, K.R., dan Hosley, R.F. 2005. Analisis Laporan Keuangan. Edisi Delapan. Jakarta: Salemba Empat.

www.duniainvetasi.com. pada tanggal 27 September 2012 pada pukul 12.00 WIB. www.google.com pada tanggal 12 Oktober 2012 pada pukul 09.00 WIB. www.idx.co.id. pada tanggal 27 September 2012 pada pukul 12.00 WIB. www.sahamok.com. pada tanggal 18 Nopember 2012 pada pukul 20.00 WIB. 